\title{
Studi Implementasi Model House of Risk (HOR) untuk Mitigasi Risiko Keterlambatan Material dan Komponen Impor pada Pembangunan Kapal Baru
}

\author{
Zulia Dewi Cahyani, Sri Rejeki Wahyu Pribadi dan Imam Baihaqi \\ Jurusan Teknik Perkapalan, Fakultas Teknologi Kelautan, Institut Teknologi Sepuluh Nopember Jl. \\ Arief Rahman Hakim, Surabaya 60111 Indonesia \\ e-mail: sri-rejeki@na.its.ac.id
}

\begin{abstract}
Abstrak-Galangan kapal dituntut menyelesaikan pembangunan kapal sesuai dengan kontrak. Ketepatan penyelesaian berhubungan dengan ketepatan pengadaan material dan komponen. Pada penelitian ini, digunakan model HOR untuk mengidentifikasi variabel risiko (risk event dan risk agent) dan mitigasi risiko. HOR digunakan pada proses bisnis umum pengadaan dan proses bisnis pengadaan setiap material dan komponen impor kategori high risk. HOR dibagi menjadi 2 fase: pertama yaitu identifikasi risiko untuk menghasilkan prioritas risk agent. Kedua adalah penyusunan tindakan pencegahan untuk menghasilkan preventive action yang efektif. Proses bisnis pengadaan dibagi menjadi 5 proses bisnis yaitu perencanaan, pembelian, pengiriman, penerimaan dan pengembalian. Identifikasi risiko dilakukan dengan melakukan penyebaran kuesioner penilaian occurrence dan severity dari variabel risiko. Pada proses bisnis umum pengadaan, risk event kategori high risk adalah krisis kepercayaan vendor terhadap kemampuan membayar perusahaan, keterlambatan dan ketidaklengkapan dokumen impor, tertahannya material di pelabuhan dan kekurangan SDM yang memenuhi kompetensi yang dibutuhkan. Dari HOR 1, dihasilkan risk agent yaitu buruknya track record galangan dalam proses pembayaran. Sedangkan pada proses bisnis pengadaan setiap material dan komponen impor ada 6 komponen kategori high risk yaitu deck machinery, navigation and communication, harbour diesel generator, main diesel engine, shafting and z-peller dan main diesel engine. Salah satu risk event yaitu lamanya negosiasi pembelian. Dari HOR fase 1, dihasilkan prioritas risk agent yaitu evaluasi teknis yang berlarut. Sehingga dari HOR 2, dihasilkan tindakan preventif untuk proses bisnis umum pengadaan adalah training peningkatan manajerial dan kemampuan masing-masing kompetensi. Sedangkan untuk proses bisnis pengadaan setiap komponen adalah mempercepat pengurusan dokumen impor komponen.
\end{abstract}

Kata Kunci-Keterlambatan, Material dan Komponen Impor Kapal, Manajemen Risiko, House of Risk (HOR)

\section{PENDAHULUAN}

$\mathrm{D}$ ALAM industri pembangunan kapal baru, sangatlah penting untuk dapat menyelesaikan pembangunan kapal sesuai dengan waktu yang telah disepakati dalam kontrak. Salah satu faktor yang menyebabkan keterlambatan pembangunan kapal adalah keterlambatan material dan komponen impor. Pada industri galangan kapal pembahasan dan analisa mengenai manajemen risiko usaha masih sangat sedikit. Sehingga diperlukan manajemen risiko terkait keterlambatan material dan komponen impor

Dalam penelitian ini akan dilakukan identifikasi risk event (kejadian risiko) dan risk agent (pemicu/penyebab risiko) pada pengadaan material dan komponen impor serta strategi mitigasi dengan menggunakan model House of Risk (HOR). Pujawan \& Geraldin, 2009 mengembangkan metode analisis risiko yang bernama House of Risk (HOR). HOR adalah pengembangan metode QFD (Quality Function Deplyoment) dan FMEA (Failure Modes and Effect Analysis) yang digunakan untuk menyusun suatu framework dalam mengelola risiko.

Pada penelitian ini digunakan model HOR, karena model ini berbeda dengan model yang sudah ada dimana pada HOR dipilih risk agent yang memiliki ARP (Aggregate Risk Potentials) tinggi yang artinya risk agent tersebut memiliki probabilitas kejadian yang tinggi dan menyebabkan banyak risk event dengan dampak yang parah. Kemudian disusun tindakan mitigasi untuk risk agent terpilih berdasarkan rasio total efektivitas untuk tingkat kesulitan dan tindakan mitigasi mana yang dapat mereduksi banyak risk agent dengan nilai ARP yang tinggi. Maka berdasarkan penjelasan diatas dilakukan sebuah penelitian yang berjudul "Studi Implementasi Model House of Risk (HOR) untuk Mitigasi Risiko Keterlambatan Material dan Komponen Impor pada Pembangunan Kapal Baru".

\section{TINJAUAN PUSTAKA}

Risiko didefinisikan sebagai probabilitas kejadian yang menyebabkan kerugian dan potensi besarnya kejadian [1].

$$
\text { Risk }=\text { Event likelihood } \times \text { Event consequence }
$$

Menajamen risiko adalah seni pembuatan keputusan dalam dunia yang penuh dengan ketidakpastian [2]. House of Risk adalah pengembangan metode QFD (Quality Function Deplyoment) dan FMEA (Failure Modes and Effect Analysis) yang digunakan untuk menyusun suatu framework dalam mengelola risiko. Metode ini bertujuan tidak hanya melakukan penanggulangan risiko tetapi juga melakukan penanggulangan terhadap penyebab risiko atau risk agent [3]. HOR memiliki dua fase yaitu pertama pertama identifikasi risiko, output-nya berupa peringkat prioritas risk agent. Fase kedua adalah penanganan risiko, outputnya-nya berupa rencana tindakan pencegahan terjadinya risk agent. 
Failure Mode and Effect Analysis (FMEA) dianggap cukup representatif dalam melakukan penilaian terhadap risiko dalam supply chain. Selain itu metode ini juga dianggap oleh para praktisi dan akademisi sebagai metode yang paling sesuai untuk menilai risiko yang timbul dalam suatu proses supply chain [4].

Pengertian Quality Function Deployment (QFD) adalah metodologi terstruktur yang digunakan dalam proses perancangan dan pengembangan produk untuk menetapkan spesifikasi kebutuhan dan keinginan konsumen, serta mengevaluasi secara sistematis kapabilitas produk atau jasa dalam memenuhi kebutuhan dan keinginan [5].

Langkah penerapan model HOR adalah sebagai berikut: 1) HOR fase 1 b. Perhitungan occurrence dan severity variabel $E_{i}$ dan $A_{j}$

c. Membangun matriks hubungan korelasi $E_{i}$ dan $A_{j}$ dengan ketentuan, 0: tidak ada korelasi, 1: korelasi lemah, 3: korelasi sedang dan 9: korelasi kuat.

d. Perhitungan nilai ARP dari $A_{j}$ menggunakan rumus:

$$
A R P_{j}=O_{j} \cdot \sum S_{i} \cdot R_{i j}
$$

e. Peringkat ARP dari masing-masing $A_{j}$.

f. Pembuatan diagram pareto $A_{j}$ (pemilihan prioritas $A_{j}$ ).

Tabel 1.

Model HOR Fase 1 [3]

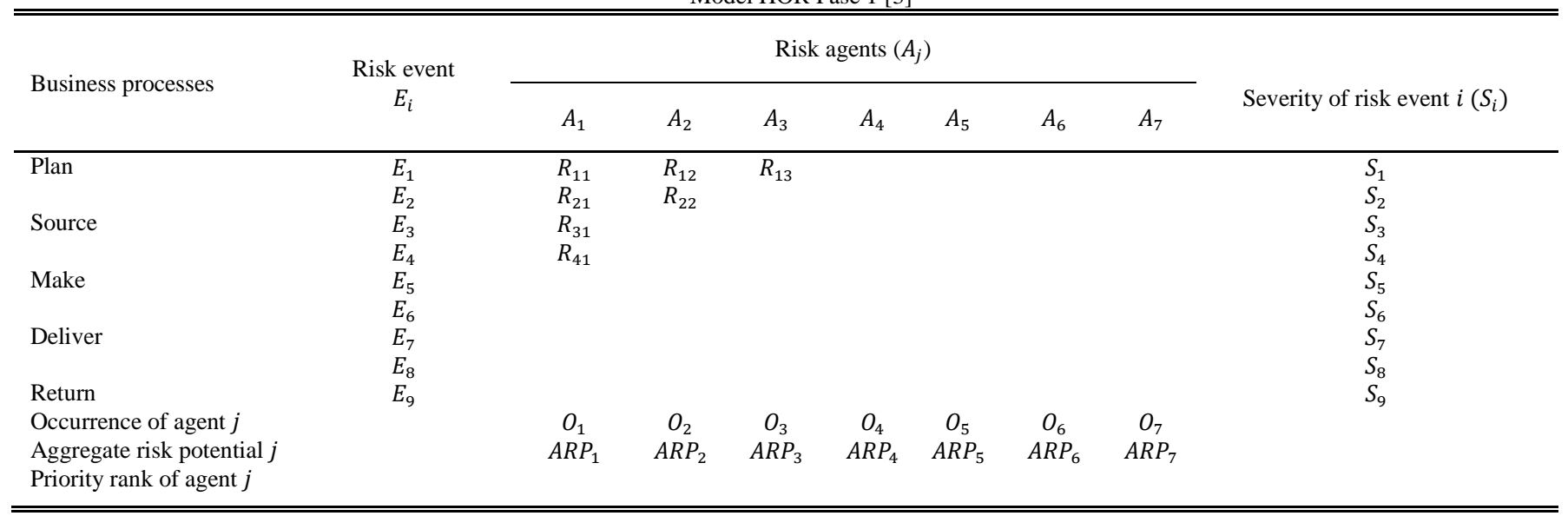

2) HOR fase 2

a. Penyusunan mitigasi atau preventive action $\left(P A_{k}\right)$ didasarkan prioritas $A_{j}$.

b. Hubungan korelasi $A_{j}$ dan $P A_{k}$ dengan ketentuan 0,1 , 3 dan 9.

c. Perhitungan nilai efektivitas total setiap $P A_{k}$ dengan rumus:

$$
T E_{k}=\Sigma\left(A R P_{j} \cdot E_{j k}\right)
$$

d. Pengukuran derajat kesulitan penerapan $P A_{k}$ dengan skala kesulitan penerapan 3: rendah, 4: sedang dan 5: tinggi.

e. Perhitungan Effectiveness to difficulty ratio dengan rumus:

$$
E T D_{k}=\frac{T E_{k}}{D_{k}}
$$

f. Peringkat prioritas $P A_{k}$ berdasarkan nilai $E T D_{k}$.
Tabel 2.

Model HOR Fase 2 [3]

\begin{tabular}{lcccccc}
\hline \hline $\begin{array}{l}\text { To be treated } \\
\text { risk agent } \\
\left(A_{j}\right)\end{array}$ & \multicolumn{5}{c}{ Preventive action $\left(P A_{k}\right)$} & $\begin{array}{l}\text { Aggregate } \\
\text { risk potential } \\
\left(A R P_{j}\right)\end{array}$ \\
\cline { 2 - 7 } & $P A_{1}$ & $P A_{2}$ & $P A_{3}$ & $P A_{4}$ & $P A_{5}$ & $A R P_{1}$ \\
\hline$A_{1}$ & $E_{11}$ & & & & & $A R P_{2}$ \\
$A_{2}$ & & & & & & $A R P_{3}$ \\
$A_{3}$ & & & & & & $A R P_{4}$ \\
$A_{4}$ & & & & & & \\
$\begin{array}{l}\text { Total } \\
\text { effectiveness } \\
\text { of action } k\end{array}$ & $T E_{1}$ & $T E_{2}$ & $T E_{3}$ & $T E_{4}$ & $T E_{5}$ & \\
$\begin{array}{l}\text { Degree of } \\
\text { difficulty } \\
\text { performing } \\
\text { action } k\end{array}$ & $D_{1}$ & $D_{2}$ & $D_{3}$ & $D_{4}$ & $D_{5}$ & \\
$\begin{array}{l}\text { Effectiveness } \\
\text { to difficulty } \\
\text { ratio } \\
\text { Rank of } \\
\text { priority }\end{array}$ & $E T D_{1}$ & $E T D_{2}$ & $E T D_{3}$ & $E T D_{4}$ & $E T D_{5}$ & \\
\hline \hline
\end{tabular}

Keterangan:

$S_{i} \quad$ : Tingkat dampak suatu risiko (severity level of risk)

$O_{j} \quad$ : Tingkat kemunculan (occurrence) risk agent

$R_{i j} \quad$ : Hubungan korelasi risk event $\mathrm{i}$ dengan risk agent $\mathrm{j}$

$A P R_{j}:$ : Aggregate Risk Potentials dari risk agent $\mathrm{j}$

$T E_{k} \quad$ : Nilai efektifitas dari setiap tindakan mitigasi $\mathrm{k}$ 
$E_{j k} \quad$ : Hubungan korelasi risk agent $\mathrm{j}$ dan mitigasi risiko $\mathrm{k}$

ETD $D_{k}:$ Effectiveness to difficulty ratio

$T E_{k} \quad:$ Total effectiveness of action $k$

$D_{k} \quad$ : Degree of difficulty performing action

\section{METODOLOGI}

Pada penelitian ini House of Risk (HOR) pertama dilakukan pada proses bisnis umum pengadaan dan kedua dilakukan pada proses bisnis setiap material dan komponen berkategori high risk. Pada penelitian ini tediri dari 4 tahap yaitu:

\section{A. Tahap Persiapan}

Pada tahap ini terdiri dari perumusan masalah dan tujuan, studi penelitian yang terdiri dari studi pustaka dan studi lapangan dan pemetaan proses bisnis menjadi 5 proses bisnis yaitu perencanaan, pembelian, pengiriman, penerimaan dan pengembalian.

\section{B. Tahap Pengumpulan dan Pengolahan Data}

Pada tahap ini dilakukan pada proses bisnis umum pengadaan dan pada proses bisnis pengadaan setiap material dan komponen impor kategori high risk. Tahap ini dilakukan identifikasi risk event dan risk agent pada kedua proses bisnis. Kemudian dilakukan pengukuran occurrence dan severity dengan menggunakan kuesioner. Kemudian dilakukan HOR fase 1 yaitu hubungan keterkaitan antara rik event dan risk agent untuk mendapatkan risk agent yang menjadi prioritas. Selanjutnya dilakukan HOR fase 2 yaitu hubungan keterkaitan risk agent dan preventive action untuk menghasilkan preventive action yang efektif.

\section{Tahap Analisa dan Pembahasan}

Pada tahap ini dilakukan analisa pada hasil HOR fase 1 dan HOR fase 2 untuk melihat faktor internal atau eksternal yang berpengaruh. Dan analisa dari preventive action.

\section{Tahap Penarikan Kesimpulan}

Penarikan kesimpulan didasarkan pada rumusan masalah dan tujuan yang telah ditetapkan pada penellitian.

\section{HASIL PENELITIAN}

\section{A. HOR Proses Bisnis Umum Pengadaan}

Ada beberapa tahapan dalam HOR pada proses ini yaitu:

1) Identifikasi risk event $\left(E_{i}\right)$ dan risk agent $\left(A_{j}\right)$.

$E_{i}$ diidentifikasi dangan model SCOR (Supply Chain Operations Reference). Membagi proses bisnis menjadi 5 yaitu perencanaan, pembelian, pengiriman, penerimaan dan pengembalian. Hasil identifikasi, $E_{i}$ berjumlah 7 pada perencanaan, 8 pada pembelian, 5 pada pengiriman, 2 pada penerimaan dan 2 pada pengembalian. Identifikasi $A_{j}$ berjumlah 35 .

2) Penyebaran kuesioner untuk menilai skala occurrence dan severity variabel $E_{i}$ dan $A_{j}$.

3) Pengujian validitas dan instrumen penelitian menghasilkan $18 E_{i}$ dan $23 A_{j}$. Pemetaan risk event menggunakan peta risiko.

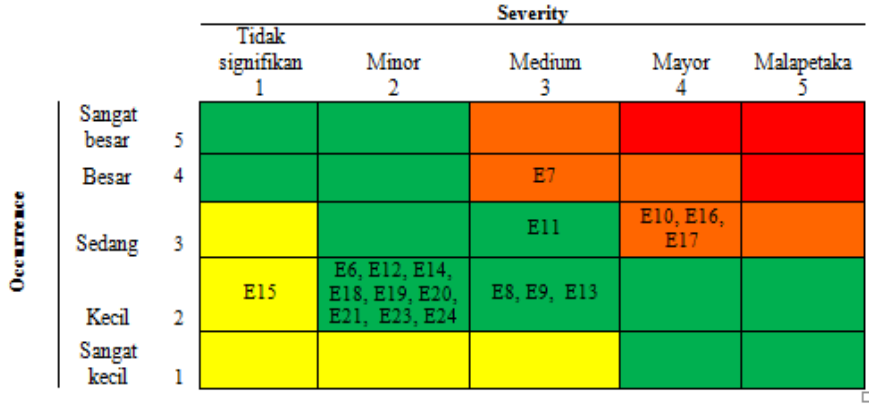

Gambar. 1. Peta Risiko Risk Event

Keterangan :

\begin{tabular}{|l|l|}
\hline & Risiko rendah \\
\hline & Risiko menengah \\
\hline & Risiko tinggi \\
\hline & Risiko ekstrim \\
\hline
\end{tabular}

Gambar. 2. Pengelompokan Peta Risiko

Pada Gambar $2 E_{i}$ dikelompokan menjadi 3 area yaitu risiko rendah, sedang dan tinggi.

4) Dilakukan hubungan korelasi $E_{i}$ dan $A_{j}$ sehingga menghasilkan nilai peringkat ARP dari $A_{j}$.

5) Penggambaran diagram pareto untuk melihat $A_{j}$ yang menjadi prioritas.

$A_{j}$ dengan persentase kumulatif lebih dari $80 \%$ akan dieliminasi dan yang ada dibawah $80 \%$ akan digunkan sebagai input HOR fase 2. Berikut gambar diagaram pareto prioritas dari $A_{j}$ :

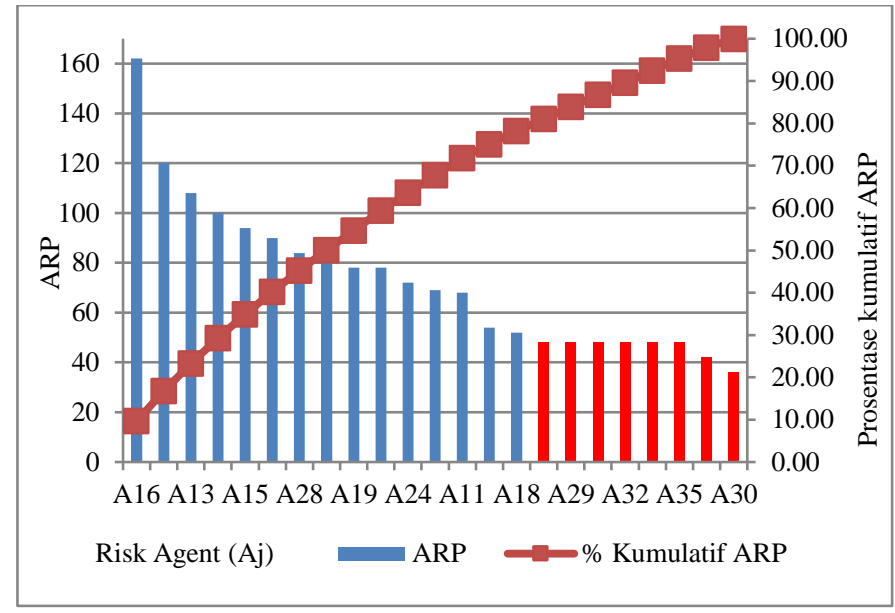

Gambar. 3. Pengelompokan Peta Risiko

Pada Gambar $3 A_{j}$ dihasilkan $15 A_{j}$ yang tidak dieliminasi terdiri dari A16, A27, A13, A26, A15, A20, A28, A17, A19, A33, A24, A9, A11, A25 dan A18 (input HOR 2).

6) HOR 2 dilakukan dengan penyusunan Preventive Action $\left(P A_{k}\right)$ untuk mitigasi.

Terpilih sebanyak $20 P A_{k}$ dan dilakukan penilaian tingkat kesulitan penerapan $P A_{k}$.

7) Dilakukan hubungan korelasi antara $P A_{k}$ dengan $A_{j}$ sehingga didapatkan nilai $T E_{k}$.

Kemudian dengan nilai kesulitan penerapan $P A_{k}$ didapatkan besarnya $E T D_{k}$ yang digunakan sebagai prioritas tindakan 
preventif yang menjadi prioritas untuk dilaksanakan. Hasil $E T D_{k}$ adalah sebagai berikut:

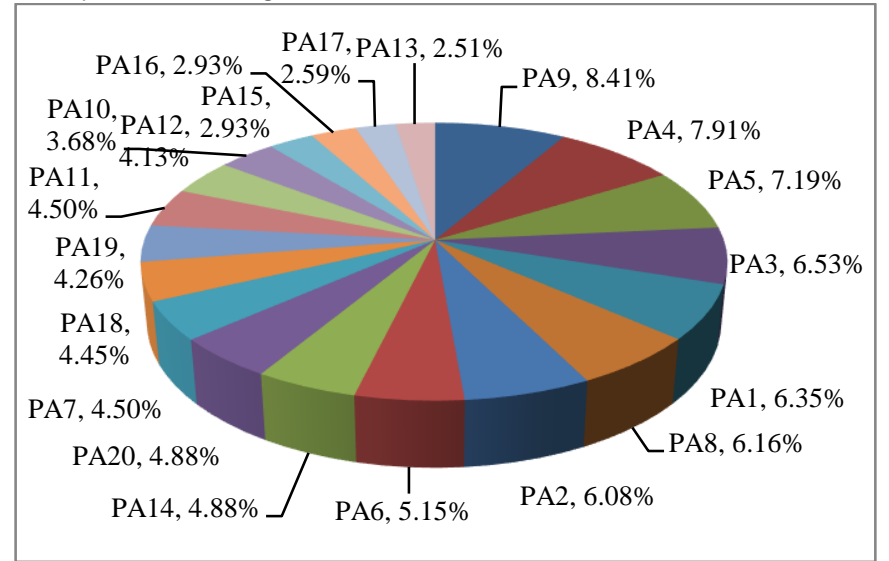

Gambar. 4. Persentase $\mathrm{ETD}_{\mathrm{k}}$ Preventive Action Proses Bisnis Umum

Pada Gambar 4 persentase tindakan preventif terbesar ada pada PA9 $(8.41 \%)$ dan persentase terendah pada PA13 $(2.51 \%)$.

\section{B. HOR Proses Bisnis Pengadaan Setiap Material dan Komponen Berisiko}

Tahapan HOR proses ini adalah:

1) Penentuan material dan komponen impor berisiko dengan melihat nilai occurrence (frekuensi keterlambatan) dan severity (kepentingan, dilihat harganya).

Hasil pemetaan risiko:

\begin{tabular}{|c|c|c|c|c|c|}
\hline \multirow{3}{*}{ 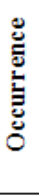 } & $\begin{array}{l}\text { Tinggi } \\
(\text { High })\end{array}$ & 3 & $\begin{array}{c}1,2,4,7,9 \\
12,13,14,15\end{array}$ & 3,11 & $5,6,10$ \\
\hline & $\begin{array}{c}\text { Sedang } \\
\text { (Medium) }\end{array}$ & 2 & & & \multirow[t]{2}{*}{8} \\
\hline & $\begin{array}{l}\text { Rendah } \\
\text { (Low) }\end{array}$ & 1 & & & \\
\hline & & & 1 & 2 & 3 \\
\hline & & & $\begin{array}{c}\text { Rendah } \\
\text { (Low) }\end{array}$ & $\begin{array}{c}\text { Sedang } \\
\text { (Medium) }\end{array}$ & $\begin{array}{l}\text { Tinggi } \\
(H i g h)\end{array}$ \\
\hline & & & & Severity & \\
\hline
\end{tabular}
1: Main Air Compressor
2: Lighting and Spare Part
9: Oily Water Separator
10: Main Diesel Generator
11: Harbour Diesel Generator
3: Deck Machinery
12: General Valves and Other
5: Main Diesel Engine
13: Cable
14: Fire Fighting System
15: Anchor and Anchor Chain
7: Pipes and Fitting
8: Navigation and Communication

Keterangan:

Gambar. 5. Peta Risiko Material dan Komponen Impor.

Pada Gambar 5 material dan komponen impor kategori risiko tinggi berjumlah 6 dan kategori risiko menegah berjumlah 9 .

2) Identifikasi $E_{i}$ dan $A_{j}$ dari komponen impor kategori high risk.
a. Deck Machinery memiliki $16 E_{i}$ dan $17 A_{j}$
b. Navigation and Communication memiliki $18 E_{i}$ dan 18 $A_{j}$
c. Harbour Diesel Generator memiliki $16 E_{i}$ dan $17 A_{j}$
d. Main Diesel Engine memiliki $16 E_{i}$ dan $17 A_{j}$
e. Shafting and Z-Peller memiliki $16 E_{i}$ dan $17 A_{j}$
f. Main Diesel Generator memiliki $16 E_{i}$ dan $17 A_{j}$

3) Pengukuran nilai occurrence dan severity dari variabel $E_{i}$ dan $A_{j}$ dengan metode kuesioner.

4) Hubungan HOR fase 1 yaitu keterkaitan antara $E_{i}$ dan $A_{j}$ sehingga menghasilkan nilai ARP dan prioritas $\mathrm{A}_{\mathrm{j}}$ setiap komponen.

- Deck Machinery memiliki $16 \mathrm{E}_{\mathrm{i}}$ dan $17 \mathrm{~A}_{\mathrm{j}}$. Prioritas $\mathrm{A} j$ dapat dilihat pada diagram pareto berikut:

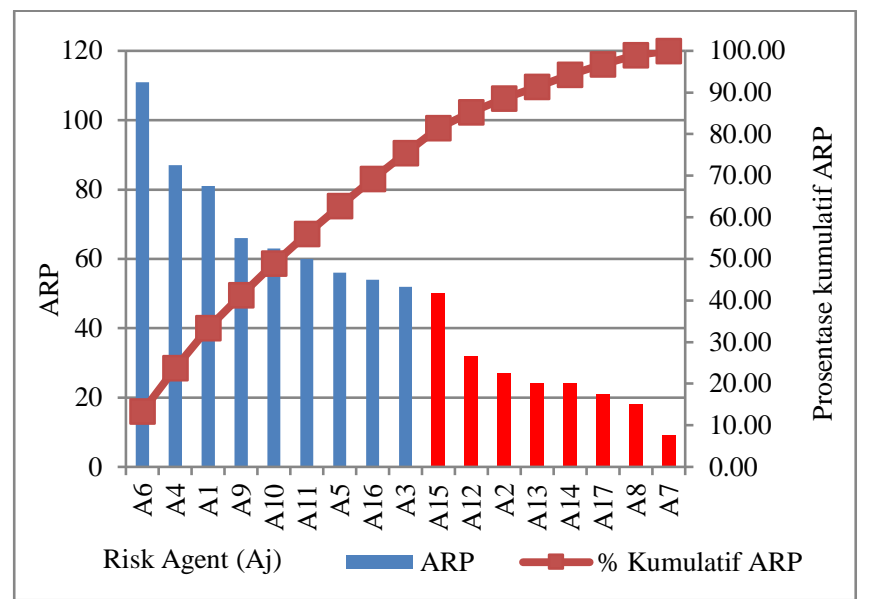

Gambar. 6. Diagram Pareto $A_{j}$ Deck Machinery

Pada Gambar 8 bahwa $A_{j}$ dengan persentase kumulatif lebih dari $80 \%$ dielimansi. $A_{j}$ yang tereliminasi berjumlah 8 (A15, A12, A2, A13, A14, A17, A8 dan A7). Sedangkan untuk $A_{j}$ yang tidak tereliminasi berjumlah 9 (A6, A4, A1, A9, A10, A11, A5, A16 dan A3).

- Navigation and Communication memiliki $18 \mathrm{E}_{\mathrm{i}}$ dan $18 \mathrm{~A}_{\mathrm{j}}$. Prioritas risk agent digambarkan dalam diagram pareto:

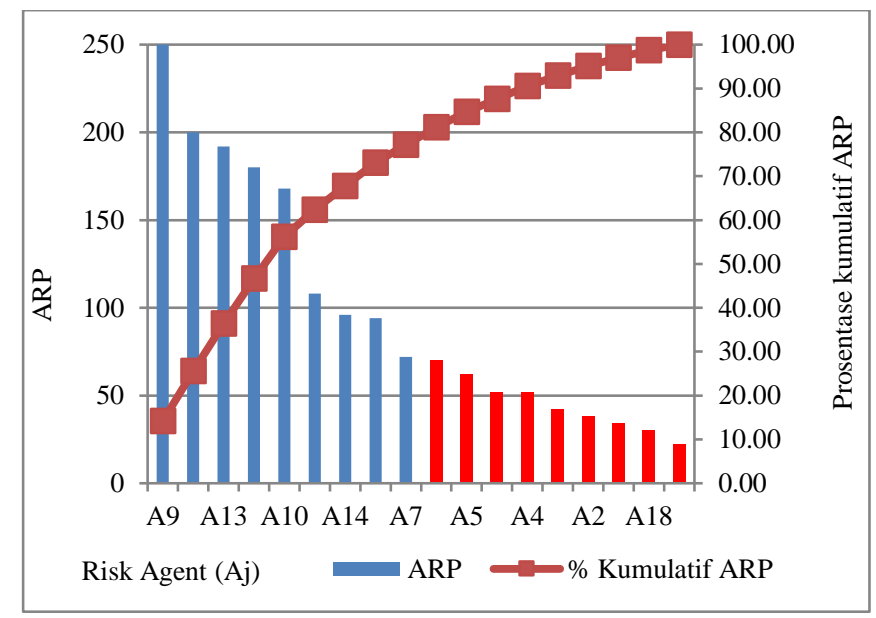

Gambar. 7. Diagram Pareto $\mathrm{A}_{\mathrm{j}}$ Navigation and Communication

Pada Gambar 7 ada 9 A $_{\mathrm{j}}$ yang tereliminasi yaitu A12, A5, A3, A4, A1, A2, A16, A18 dan A17. Sedangkan $A_{j}$ yang digunakan untuk HOR fase 2 berjumlah 9 yaitu A9, A15, A13, A11, A10, A8, A14, A6 dan A7.

- Harbour Diesel Generator memiliki $16 \quad \mathrm{E}_{\mathrm{i}}$ dan $17 \mathrm{~A}_{\mathrm{j}}$. Prioritas risk agent dalam diagram pareto: 


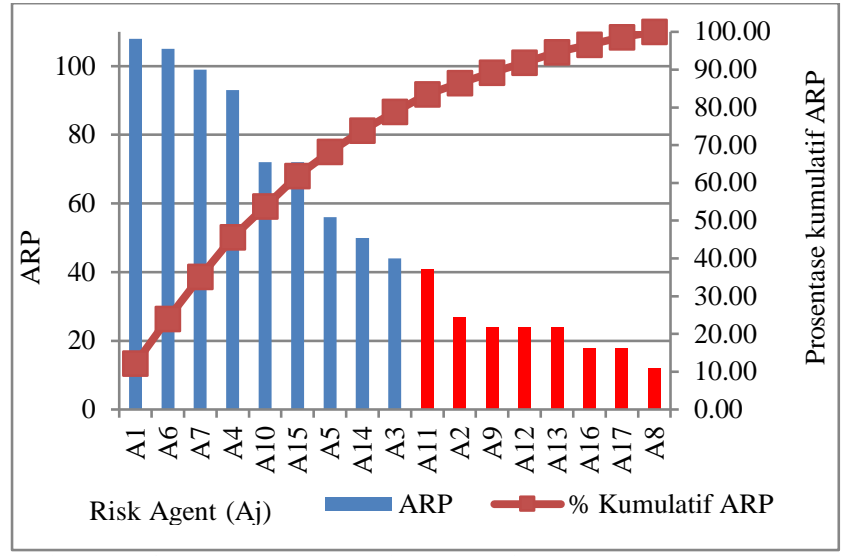

Gambar. 8. DiagramPareto $\mathrm{A}_{\mathrm{j}}$ Harbour Diesel Generator

Pada Gambar $10 \mathrm{~A}_{\mathrm{j}}$ yang tereliminasi ada 8 (A11, A2, A9, A12, A13, A16, A17 dan A8). Sedangkan $A_{j}$ yang lolos eliminasi ada 9 (A1, A6, A7, A4, A10, A15, A5, A14 dan A3).

- Main Diesel Engine memiliki $16 E_{i}$ dan $17 A_{j}$. Hasil prioritas risk agent ditunjukan dalam diagram pareto:

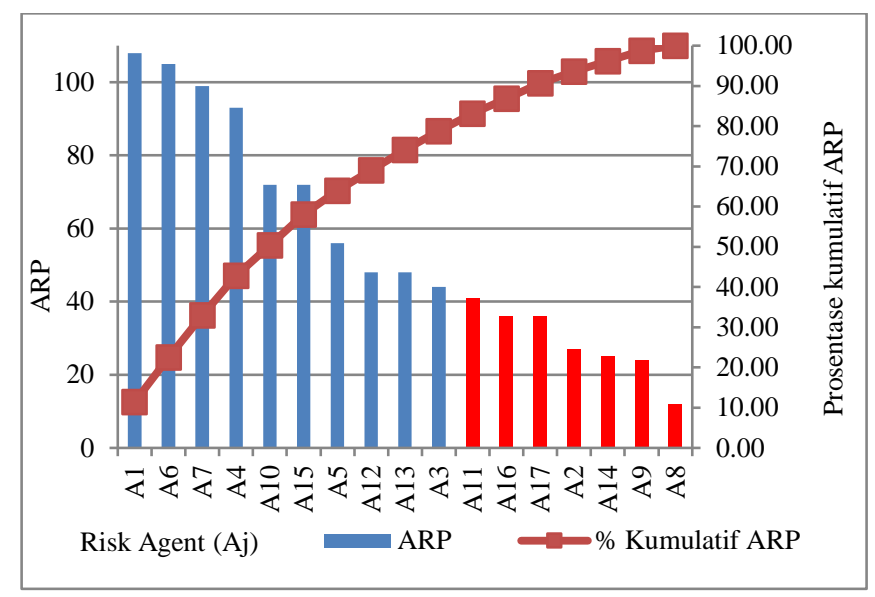

Gambar. 9. Diagram Pareto $\mathrm{A}_{\mathrm{j}}$ Main Diesel Engine

Berdasarkan Gamabr $11 \mathrm{~A}_{\mathrm{j}}$ tereliminasi berjumlah 7 (A11, A16, A17, A2, A14, A9 dan A8). Sedangkan yang lolos eliminasi berjumlah 10 (A1, A6, A7, A4, A10, A15, A5, A12, A13 dan A3).

- Shafting and Z-Peller memiliki $16 E_{i}$ dan $17 A_{j}$. Hasil prioritas risk agent digambarkan pada diagram pareto:

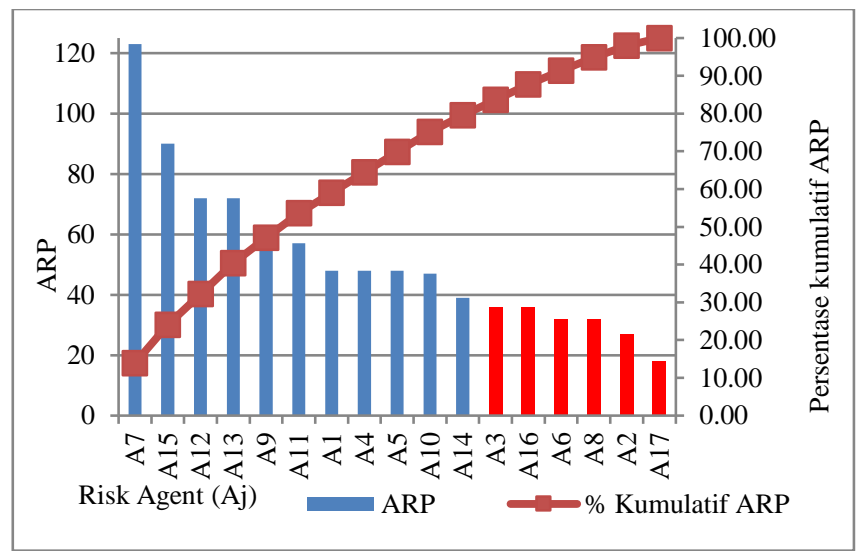

Gambar. 10. Diagram Pareto Aj Shafting and Z-peller
Pada Gambar 12 terdapat $6 \mathrm{~A}_{\mathrm{j}}$ (A3, A16, A6, A8, A2 dan A17) tereliminasi. Sedangkan yang lolos eliminasi ada $11 \mathrm{~A}_{\mathrm{j}}$ (A7, A15, A12, A13, A9, A11, A1, A4, A5, A10 dan A14).

- Main Diesel Generator memiliki $16 E_{i}$ dan $17 A_{j}$. Prioritas risk agent ditunjukan pada diagram pareto berikut:

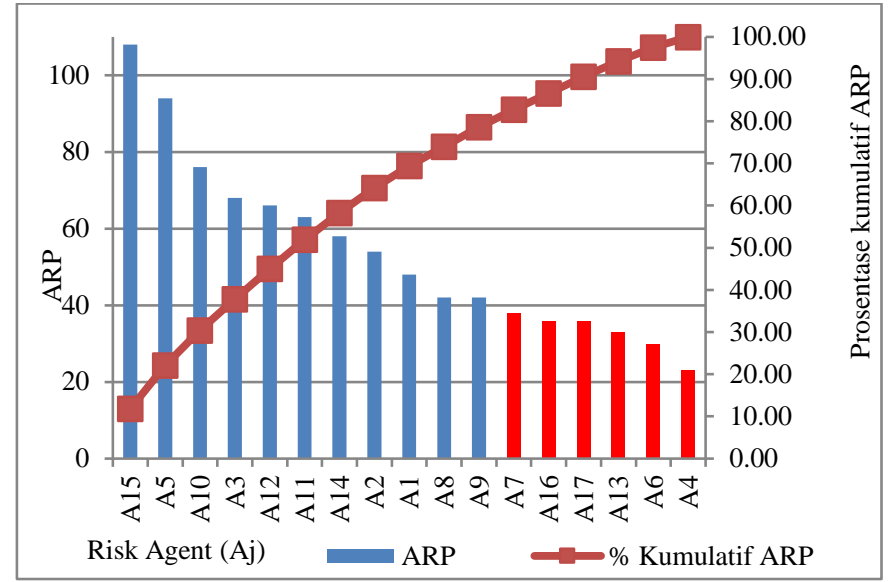

Gambar. 11. Diagram Pareto $\mathrm{A}_{\mathrm{j}}$ Main Diesel Generator

Berdasarkan Gambar 13 ada 6 A (A7, A16, A17, A13, A6 dan A4) tereliminasi. Ada $11 \mathrm{~A}_{\mathrm{j}}(\mathrm{A} 15, \mathrm{~A} 5, \mathrm{~A} 10, \mathrm{~A} 3, \mathrm{~A} 12, \mathrm{~A} 11$, A14, A2, A1, A8 dan A9) tidak tereliminasi.

5) Setelah hubungan HOR fase 1, kemudian dilakukan HOR fase 2 dengan menggunakan hubunga korelasi prioritas risk agent $\left(\mathrm{A}_{\mathrm{j}}\right)$ dengan Prevetif Action $\left(\mathrm{PA}_{\mathrm{k}}\right)$, juga nilai derajat kesulitan penerapan $\mathrm{PA}_{\mathrm{k}}\left(\mathrm{D}_{\mathrm{k}}\right)$. Hasil dari hubungan HOR fase 2 adalah persentasi $\mathrm{ETD}_{\mathrm{k}}$ yang digunkan untuk prioritas $\mathrm{PA}_{\mathrm{k}}$.

\section{- Desk Machinery}

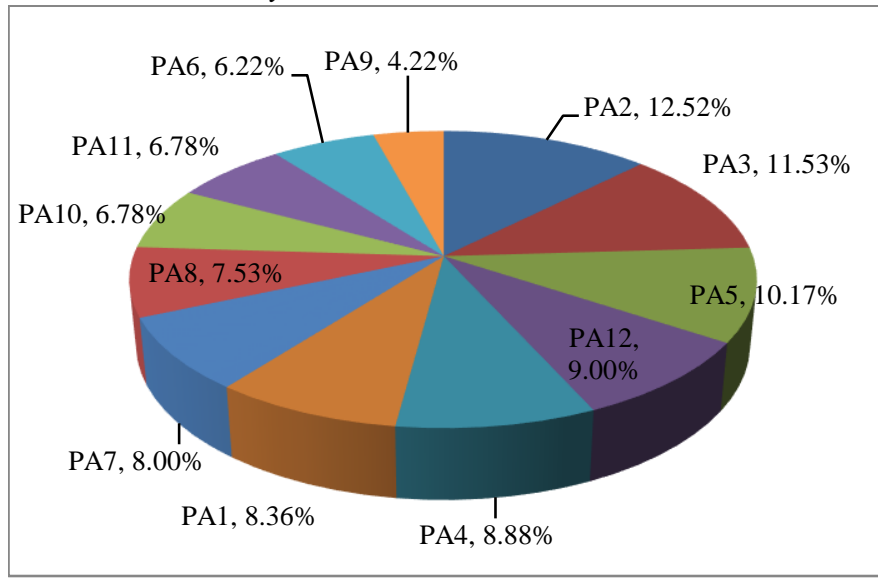

Gambar. 12. Persentase $\mathrm{ETD}_{\mathrm{k}} \mathrm{PA}_{\mathrm{k}}$ Deck Machinery

Pada Gambar 12 persentase terbesar untuk nilai $\mathrm{ETD}_{\mathrm{k}}$ dari $\mathrm{PA}_{\mathrm{k}}$ adalah $15.52 \%$ yang terdapat pada PA2 (Penyederhanaan sistem dan prosedur). Sedangkan nilai persentase terkecil adalah $4.22 \%$ yang terdapat pada PA9 (Meningkatkan kemampuan dan kepastian membayar perusahaan). 
- Navigation and Communication

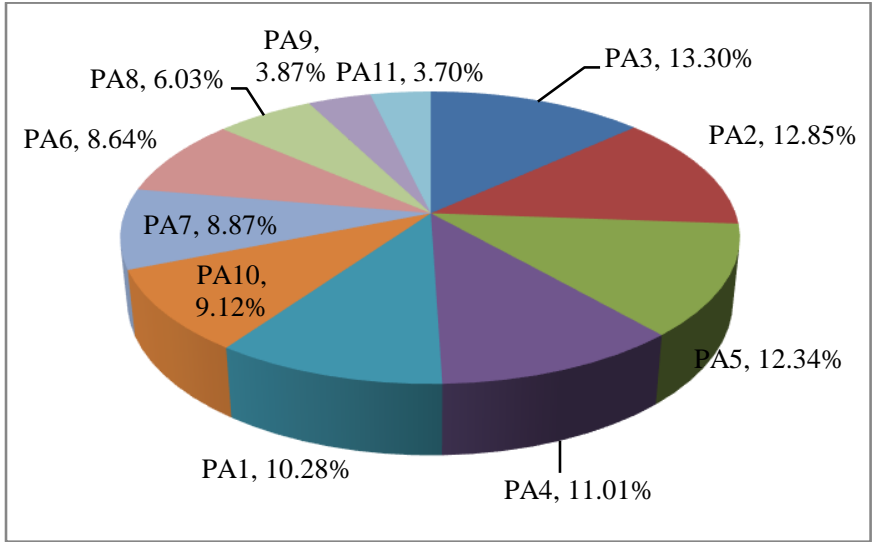

Gambar. 13. Persentase $\mathrm{ETD}_{\mathrm{k}} \mathrm{PA}_{\mathrm{k}}$ Navigation and Communication

Dapat dilihat pada Gambar 13 persentase terbesar nilai $\mathrm{ETD}_{\mathrm{k}}$ terdapat pada PA3 dengan nilai sebesar $13.30 \%$ sedangkan persentase terkecil terdapat pada PA11 dengan nilai $3.70 \%$.

\section{- Harbour Diesel Generator}

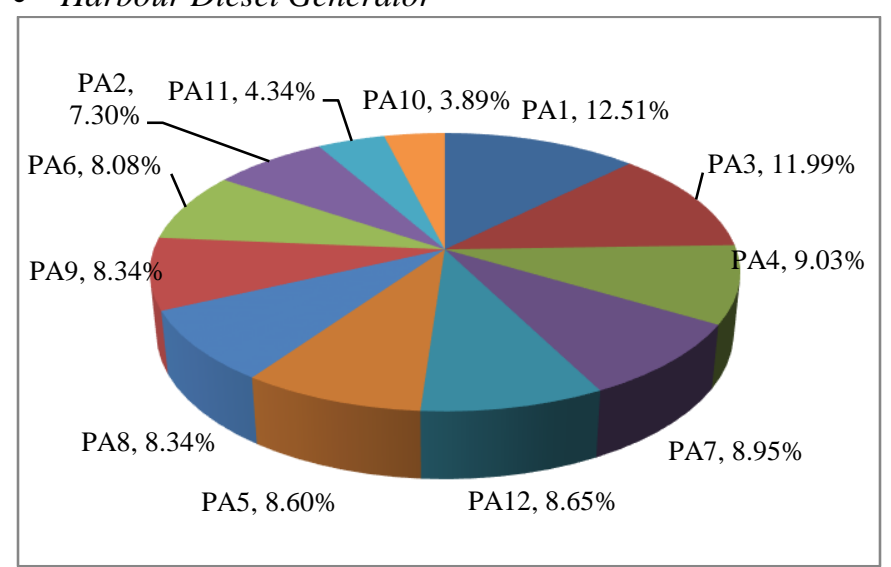

Gambar. 14. Persentase $\mathrm{ETD}_{\mathrm{k}} \mathrm{PA}_{\mathrm{k}}$ Harbou Diesel Generator

Dari Gambar 14 maka diketahui nilai $\mathrm{ETD}_{\mathrm{k}}$ terbesar terdapat pada PA3 (persenatse 11.99\%) dan ETDk terkecil pada PA10 (persentase 3.89\%).

\section{- Main Diesel Engine}

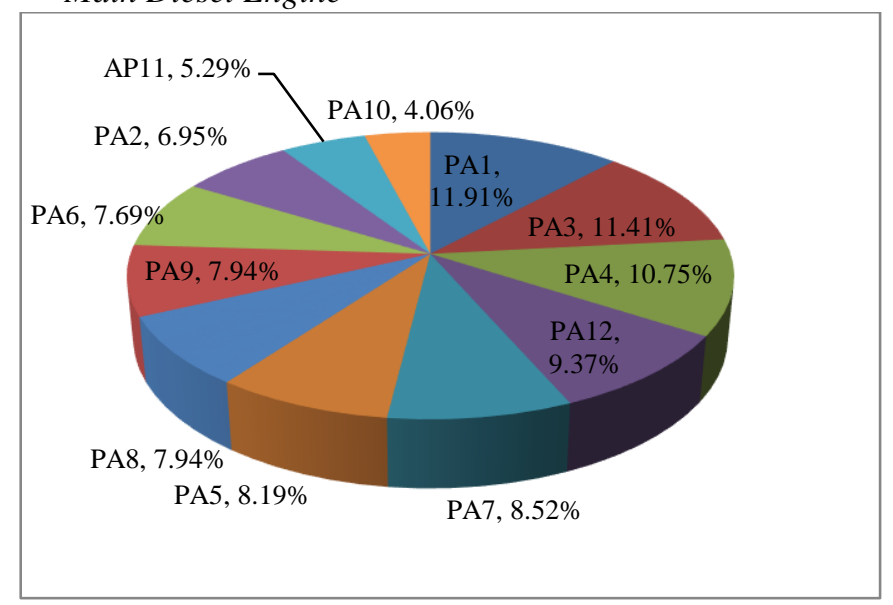

Gambar. 15. Persentase $\mathrm{ETD}_{\mathrm{k}} \mathrm{PA}_{\mathrm{k}}$ Main Diesel Engine

Pada Gambar 15 persentase terbesar adalah $11.41 \%$ yang terdapat pada PA3 dan persentase terkecil adalah PA10 dengan besar $4.06 \%$.
- Shafting and Z-Peller

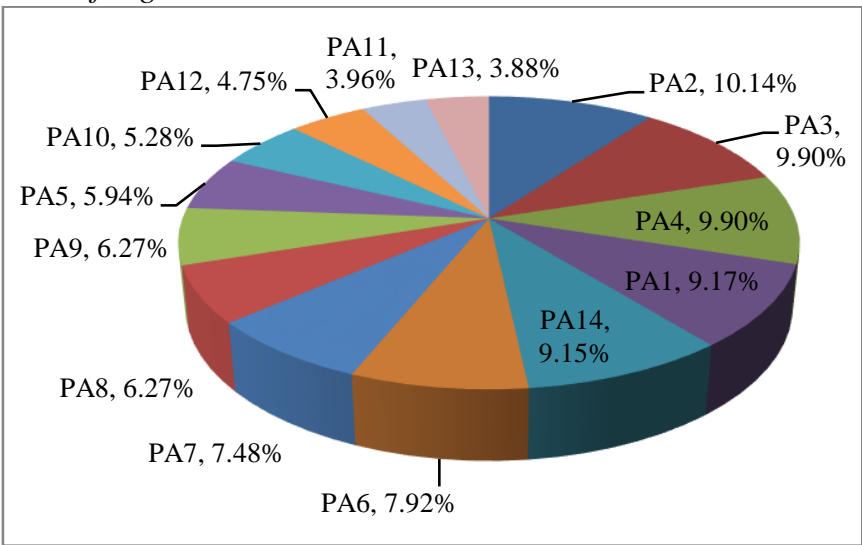

Gambar. 16. Persentase $\mathrm{ETD}_{\mathrm{k}} \mathrm{PA}_{\mathrm{k}}$ Shafting and Z-Peller

Berdasarkan Gambar 18 dapat dilihat persentase $\mathrm{ETD}_{\mathrm{k}}$ terbesar adalah pada PA3 (9.90\%) dan persentase terkecil terdapat pada PA13 (3.88\%).

\section{- Main Diesel Generator}

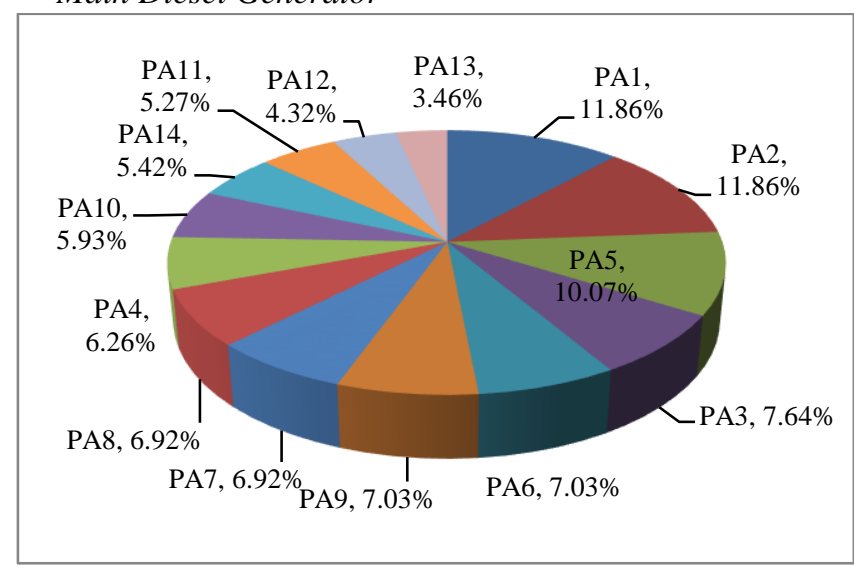

Gambar. 17. Persentase $\mathrm{ETD}_{\mathrm{k}} \mathrm{PA}_{\mathrm{k}}$ Shafting and Z-Peller

Nilai persentase terbesar adalah $11.86 \%$ yang terdapat pada PA1 dan persentase terkecil adalah $3.46 \%$ yang terdapat pada PA13.

\section{ANALISA DAN PEMBAHASAN}

Analisa dan pembahasan dilakukan pada proses bisnis umum pengadaan dan proses bisnis pengadaan setiap komponen impor kategori high risk.

\section{A. Proses Bisnis Umum Pengadaan}

1) Hasil pemetaan risiko didapatkan bahwa risk event yang masuk ke dalam kategori high risk : kekurangan SDM yang memenuhi kompetensi yang dibutuhkan; krisis kepercayaan vendor (pemasok) terhadap kemampuan membayar perusahaan; keterlambatan dan ketidaklengkapan dokumen impor; dan tertahannya material dan komponen di pelabuhan.

2) Berdasarakan hasil pengolahan HOR fase 1 didapatkan peringkat prioritas $A_{j}$ dimana terdapat $15 \quad A_{j}$ yang digunakan dan $8 \mathrm{~A}_{\mathrm{j}}$ dieliminasi. Berikut 3 rangking tinggi dari $A_{j}$ : buruknya track record galangan dalam proses pembayaran; kesiapan pendanaan custom clearance belum 
mendukung; dan detail spesifikasi dari material dan komponen yang belum lengkap.

3) Hasil HOR fase 2 adalah prioritas dari Preventive Action $\left(\mathrm{PA}_{\mathrm{k}}\right)$, ada $20 \mathrm{PA}_{\mathrm{k}}$ dan 3 peringkat $\mathrm{PA}_{\mathrm{k}}$ atas: training peningkatan manajerial dan kemampuan masing-masing kompetensi; pelibatan divisi desain dan project team pada proses evaluasi teknis terutama untuk main equipment; dan melakukan koordinasi intensif dengan divisi desain untuk kejelasan spesifikasi material dan komponen.

\section{B. Proses Bisnis Pengadaan Setiap Komponen Impor yang Berisiko Tinggi}

Hasil dari HOR Fase 1 untuk setiap komponen impor adalah prioritas dari risk agent, dimana risk agent dengan ARP tinggi berarti memiliki frekuensi kejadian sering dan mempengaruhi risk event yang memiki severity tinggi. Hasil HOR fase 1 komponen impor yang berisiko tinggi:

\section{1) Deck Machinery}

Terdapat $17 \mathrm{~A}_{\mathrm{j}}$ yang menjadi prioritas. Berikut $3 \mathrm{~A}_{\mathrm{j}}$ yang menjadi peringkat atas adalah alokasi SDM yang tidak sesuai beban kerja; detail spesifikasi komponen masih belum lengkap; dan bank data katalog tidak ter-update dan terpelihara dengan baik.

2) Navigation and Communication

Terdapat $18 \mathrm{~A}_{\mathrm{j}}$ yang menjadi prioritas. Berikut $3 \mathrm{~A}_{\mathrm{j}}$ pada peringkat atas adalah evaluasi teknis yang berlarut-larut; pembengkakan biaya storage komponen yang tertahan di pelabuhan; dan spesifikasi komponen yang tidak bisa dipenuhi oleh satu supplier.

\section{3) Harbour Diesel Generator}

Terdapat $17 \mathrm{~A}_{\mathrm{j}}$ yang menjadi prioritas. Berikut $3 \mathrm{~A}_{\mathrm{j}}$ yang menjadi tingkat atas yaitu bank data katalog tidak ter-update dan terpelihara dengan baik; alokasi SDM yang tidak sesuai dengan beban kerja; dan evaluasi teknis yang berlarut-larut.

4) Main Diesel Engine

Terdapat $17 \mathrm{~A}_{\mathrm{j}}$ yang menjadi prioritas. $\mathrm{A}_{\mathrm{j}}$ yang menjadi 3 peringkat atas adalah bank data katalog tidak ter-update dan terpelihara dengan baik; alokasi SDM yang tidak sesuai dengan beban kerja; dan evaluasi teknis yang berlarut-larut.

5) Shafting and Z-Peller

Terdapat $17 \mathrm{~A}_{\mathrm{j}}$ yang menjadi prioritas. Dimana $3 \mathrm{~A}_{\mathrm{j}}$ pada peringkat atas adalah evaluasi teknis yang berlarut-larut; komponen ditempatkan pada tempat yang tidak semestinya; dan keterlambatan dokumen impor.

\section{6) Main Diesel Generator}

Terdapat $17 \mathrm{~A}_{\mathrm{j}}$ yang menjadi prioritas. Sementara $3 \mathrm{Aj}$ yang menjadi peringkat atas yaitu komponen ditempatkan pada tempat yang tidak semestinya, buruknya track record pembayaran; dan ketidakakuratan penjabaran budget.

\section{KESIMPULAN}

Berdasarkan hasil dan pembahasan, maka kesimpulan dari tugas akhir ini adalah:

1) Identifikasi material dan komponen impor dilakukan dengan pengukuran occurrence dan severity. Sehingga didapatkan material dan komponen impor yang termasuk ke dalam kategori high risk ada 6 yaitu: deck machinery, navigation and communication, harbour diesel generator, main diesel engine, shafting and z-peller dan main diesel generator.

2) Pada proses bisnis umum pengadaan dengan HOR fase 1 didapatkan:

a. Terdapat 4 risk event yang masuk ke dalam kategori high risk: kekurangan SDM yang memenuhi kompetensi yang dibutuhkan; krisis kepercayaan vendor (pemasok) terhadap kemampuan membayar perusahaan; keterlambatan dan ketidaklengkapan dokumen impor; dan tertahannya material dan komponen di pelabuhan.

b. Prioritas risk agent adalah buruknya track record galangan dalam proses pembayaran. Dibuktikan dengan nilai ARP tinggi yaitu sebesar 162.

3) Pada proses bisnis pengadaan komponen high risk dengan HOR fase 1 didapatkan:

a. Risk event penyebab keterlambatan pengadaan yaitu lamanya negosiasi pembelian, PO diterbitkan tidak sesuai dengan anggaran dan jadwal, penambahan biaya jasa untuk melakukan pengadaan banyak komponen, tertahannya komponen di pelabuhan, penambahan biaya pengeluaran komponen yang tertahan dipelabuhan.

b. Risk agent yang menjadi prioritas adalah evaluasi teknis yang berlarut, dibuktikan dengan nilai ARP tinggi 250.

4) Berdasarkan HOR fase 2, preventive action:

a. Proses bisnis umum pengadaan: training peningkatan manajerial dan kemampuan masing-masing kompetensi.

b. Proses bisnis pengadaan komponen high risk: mempercepat pengurusan dokumen impor komponen.

\section{UCAPAN TERIMA KASIH}

Penulis mengucapkan terima kasih kepada pihak-pihak yang membantu penyelesaian Tugas Akhir ini, yaitu: Ibu Sri Rejeki Wahyu Pribadi, S.T.,M.T dan.Bapak Imam Baihaqi, S.T., M.T selaku Dosen Pembimbing atas bimbingan dan motivasinya. Bapak Ir. Heri Supomo, M.Sc dan Ir. Triwilaswandio W.P., yang telah banyak membantu penulis. Bapak dan Ibu Dosen Penguji sekaligus Penelaah. Dosen Jurusan Teknik Perkapalan khususnya bidang industri perkapalan yang juga membantu dalam penyelesaian tugas akhir ini. Departemen pengadaan dan unit manajemen risiko galangan kapal PT X yang telah bersedia membantu mendapatkan data dalam penyelesaian tugas akhir ini. Serta pihak lainnya yang ikut membantu terselesaikannya penelitian ini, yang tidak bisa penulis sebutkan satu per satu.

\section{DAFTAR PUSTAKA}

[1] K. M. W., Pipeline Risk Management Manual, USA: Gulf Professional Publishing, 2004.

[2] B. F., Manajemen Risiko, Jakarta: PT. Grasindo, 2007. 
[3] P. L. and G. L., "A Model for Proactive Supply Chain Risk," Bussiness Process Management Hournal, 2009.

[4] M. C. P. and H. A. H., Creating Resilient Supply Chain: A Partical Guide, UK: Center for Logistic and Supply Chain Management, Cranfield School Management, 2003
[5] C. L., Quality Function Deployment How to Make QFD Work for You, 1995 